Newton, has put the manuscripts, or such as they have now, in the hands of all serious workers, from Horsley to L. T. More. Viscount Lymington, the heir of the Earl of Portsmouth, has now instructed Messrs. Sotheby to sell them. It might thus seem that there was little except personal matters to find. Many of the letters have been published, accurately or inaccurately, whole or in part, in various wellknown sources. But the list includes, for example, such items as "three thick folio volumes", which we did not know of, relating to the Mint and containing documents in Newton's hand. It makes one leave in suspense the Cambridge report, that "Newton's manuscripts on Alchemy are of very little interest in themselves", probable as this may seem in itself, and though the syndicate contained one notable chemist. Also Messrs. Sotheby have added some celebrated portraits to their list. The sale should be well attended; for though most of the contents that are valuable are available, many would like a copy of Newton's beautiful handwriting and that of his contemporaries, apart from those that contemplate a more extensive purchase.

\section{National Inland Water Survey}

The first Annual Report of the Committee appointed in January, 1935, jointly by the Minister of Health and the Secretary of State for Scotland, "to advise on the Inland Water Survey for Great Britain, on the progress of the measures undertaken and on further measures required and, in particular, to make an annual report on the subject", has been awaited with keen antieipation in many quarters, and especially by those engaged in the use and exploitation of the water supplies of Great Britain. It was scarcely to be expected, however, that during the first year of its existence, the Committee would be able to achieve any remarkable results. Its first duty was, naturally, to review the existing conditions and to ascertain the extent to which processes and methods in vogue could be adapted to some uniform and standardized system of procedure. The purpose of the survey, as set out in the Report now issued (London: H.M. Stationery Office. 3d. net.), "is to correlate the information at present obtained from all sources, to extend and increase the sources of information, and to make the information readily available for the use of the interests concerned". This has involved exploratory investigations in various directions and the issue of inquiries, which took the form of a detailed questionnaire (reproduced in an appendix to the Report) to which replies have been received from about 3,000 bodies and persons. The replies show that there is a good deal of information available, but that it is varied in type and date, is insufficient and lacks co-ordination and distribution-an endorsement of the conclusions arrived at by the British Association Committee in its report to the Leicester meeting, 1933.

The present Committee has, accordingly, directed its attention to the means by which an improved system of gauging and recording could be attained. At the same time, it has been conscious of the desirability on economical grounds of adopting as gauging stations a number of structures not originally designed for the purpose, and of obtaining measurements from weirs of a type perhaps not best suited to the end in view. It is of opinion, as advocated in Nature (Nov. 5, 1932 ; and again, Aug. 4, 1934), when the matter was first under public consideration, that the Catchment Boards of England and Wales, established under the Land Drainage Act, 1930, are the appropriate bodies to instal gauging stations on rivers and to make and record the measurements of the flow of the rivers which they control. The co-operation of the Catchment Boards has therefore been sought with results which are described as encouraging, and, as there is a large area in England and Wales not yet under the jurisdiction of any catchment board, the Committee has concentrated attention for the time being on areas for which Catchment Boards have been appointed. As regards underground water, the aid of the Geological Survey has been enlisted with the approval of the Committee of the Privy Council for Scientific and Industrial Research. In estimating the value of the existing gauging stations for measuring overground water, an examination has been made of three selected rivers - the Nene, the Thames and the Clyde-and a section of the Report deals with each of them in detail. After setting out its proposals for the publication of data, the Committee concludes the Report with an expression of satisfaction at what it has been able to accomplish in the first year of its existence.

\section{Britain's Largest Hydro-Electric Development}

AN aggregate of 102,000 kilowatt of plant is installed in five power stations in Kirkcudbrightshire and Wigtownshire in the south-west of Scotland. When the Water-Power Sources Committee presented its report in 1924, this portion of Scotland was defined as a place where there were possibilities of water-power development, but it was not surveyed as no commercial outlet for the power could then be visualized. The formation of the Grid, by providing the necessary power outlet, showed how a commereial application was possible, and the present hydroelectric scheme was developed as an important factor in the Central Scotland Grid scheme. In the Electrical Times for June 25 there is a detailed account of this scheme, called the Galloway Water Power Scheme, which generates the greatest amount of hydroelectric power of any station in Great Britain. In any power scheme the peak units are by far the most expensive. With steam generation, for example, a large amount of plant capacity has to be provided to cover the period of maximum demand. Daily peaks also occurring at regular intervals are expensive owing to the stand-by coal required. In these circumstances, we can see that hydro-electric plant, which can pick up and drop load at very short notice either in normal operation or in emergency, is a very valuable asset. The Galloway undertaking is unique amongst power stations, as it was planned and carried out as a peak load station instead of supplying the usual basic load. It has already proved valuable 